\title{
片麻痺者用車いすの設計・開発
}

\section{Design and development of wheelchair for hemiplegic patient}

\begin{abstract}
南後淳 - 山形大学大学院理工学研究科 三吉洋太 - 山形大学大学院理工学研究科 田中裕輔 - 山形大学大学院理工学研究科
\end{abstract}
Jun Nango, Yamagata University

Yota Miyoshi, Yamagata University

Yusuke Tanaka, Yamagata University

Key Words: Wheelchair, Six-bar Linkage, Angular Displacement, Leg Motion

\section{論文要旨}

It is difficult for the hemiplegic patients to move the side of the body paralyzed due to apoplexy. And they need to recover their motor function through a course of rehabilitations. While, the wheelchair is used as a self-supported transfer by the hemiplegic patients. It is likely to driven by the healthy side on their own. However, if the hemiplegic patients continue to drive the wheelchair by limbs on the healthy side, the muscular force of the affected side will be weakened with a risk of a slow recovery. In this paper, we design and manufacture the wheelchair that gives the paralyzed limbs gait training motion for hemiplegic patient. This gait training motion is generated by the healthy side as driving wheelchair. Giving the repeated motion to the affected side, the wheelchair is expected to bring an effective rehabilitation. We measure the angular displacement of hip joint and knee joint and examine the effect of the wheelchair.

\section{1.緒言}

片麻痺者は,脳卒中などによる右半身または左半身の麻㾝 の影響で患側の運動が困難であり,リハビリテーションによ ってその運動機能を回復することが望まれている.しかし,特 に歩行のリハビリテーションは介助者の力を借りなければ 行うことができない場合もあり,介助者に負担がかかるだけ に介護を受ける側にとってリハビリテーションに抵抗があ るということも事実である.一方、脳卒中片麻潮患者の移動手 段の一つとして車いすがあり、自力で駆動する方法として健 側による駆動が多くみられる.しかし，日常生活の中で健側の みの使用を続けると,患側に残存している筋力の低下につな がり、回復が遅れてしまう問題があり,健側のみではなく患側 の運動が必要である.

本研究では,リンク機構を用いた脚部のリハビリテーショ ンを目的とした片麻㾝者用脚部駆動車いすの設計・製作を行 う.健側駆動の構造とすることで自力での移動が可能となり， リンク機構を用いることにより患側も追従し,患側に反復運 動を与えることによるリハビリテーション効果が期待でき る.本研究では運動障害が残る可能性が高い左半身麻溥者を 対象とした装置の設計を行い,試作した 2 つの車いすについ て,健常者を対象とした実験的な評価を行い,さらに改良につ いても検討する。

\section{2.車いすの構造}

\section{2-1 試作した 2 種類の車いす}

Fig.1 に試作した脚部駆動の平面 4節リンク機構を用いた 2 種類の実験装置を示す.また,Fig.2 に機構図を,Fig.3にはそれ ぞれの装置で計測した角変位のグラフを示す.

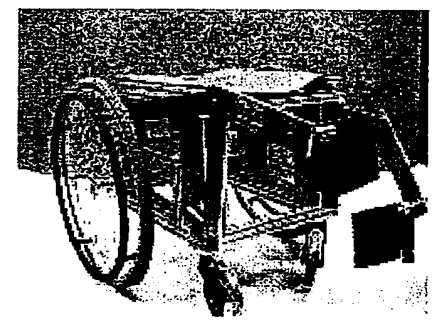

(a)Type 1

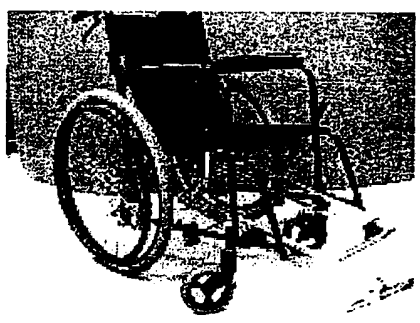

(b)Type 2
Fig.1 Trial device

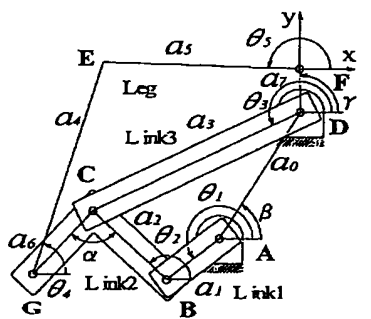

(a)Type 1

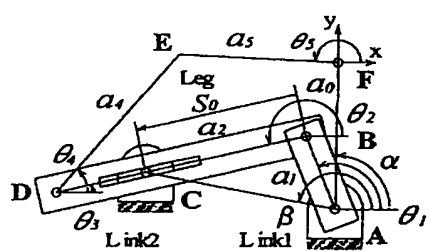

(b)Type 2
Fig.2 Kinematic model

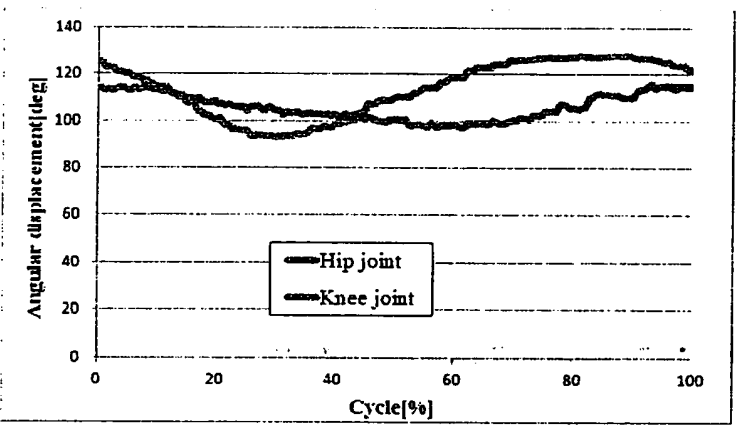

(a)Type 1

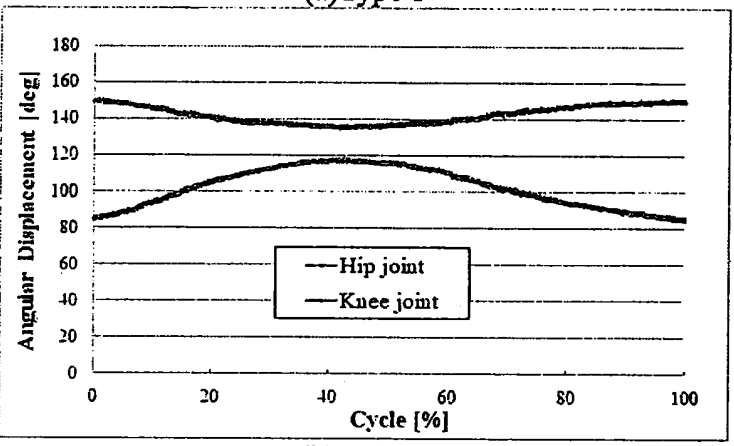

(b) Type 2

Fig.3 Angular displacement

Type1 は股関節の可動域拡大を目的とした,マッサージの 動きを参考にした 4 節リンク機構の車いす,Type2 は大腿部の 筋力を刺激する目的とした,スクワットの動きを参考にした スライダリンク機構の車いすである.Type1 の車いすは装置 
を駆動する際,脚部の大腿部が上がりすぎるため,姿勢の安定 性に欠け,リンクが露出していることから移乗の不便さが問 題点として挙げられる.また Type2 の車い寸は股関節の可動 域が小さく、漕ぎにくいことが問題となる.

\section{2-2 改良型の機構}

前節に示した問題点を解決するため,脚部股関節の可動域 を制限し,足関節が前後に動くような機構を新たに採用す る.Fig.5 に新しく採用した平面 6 節リンク機構を用いた機構 図を,Fig.6に試作した装置を示す.なお,平面6節リンク機構の 機構定数決定方法は健常者が車いすに乗り床を蹴って進む ときの駆動時の脚部の摇動幅を参考とし,そのときの股関節 および膝関節の角変位を測定し,脚部が創成する動きと,装置 使用時に創成される動きを一致させるようにし,車いすの座 面の下にリンク機構が収まるように決定する.また,片手片足 駆動でも旋回や方向転換ができ，かつ患側脚部が健側の脚部 に追従して動くようにするために,Fig.7 のように車軸を分離 させ,健側である右足で左車輪を,右手で右車輪を駆動する形 式とするこことき,脚部で駆動する機構は左右で出力軸（車 軸）を共有することで,健側の脚部運動により,患側にも位相 を反転させた運動をさせることが可能となる。

\section{3.改良型の実験的評価}

\section{3-1 角変位の測定}

Fig.8 はポテンショメータを用いて人体脚部関節角変位を 測定した脚部の動きを表している.Fig.8(a)は設計時に参考と した車いす使用時の床を蹴る動作を示し,Fig.8(b)は製作した リンク機構で車いすを駆動する動作を示している.
Fig. 5 Kinematic model

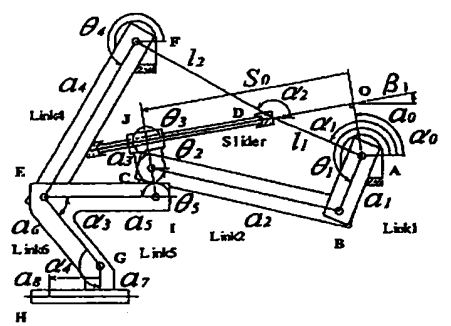

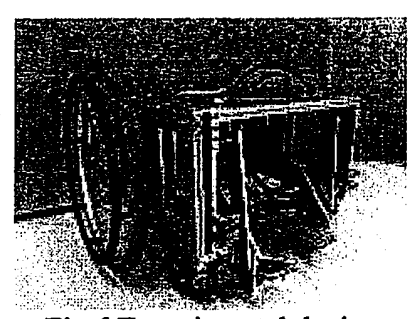

Fig.6 Experimental device

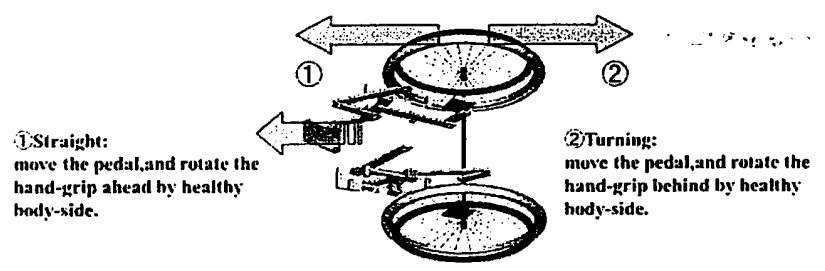

Fig.7 Mechanics of shaft

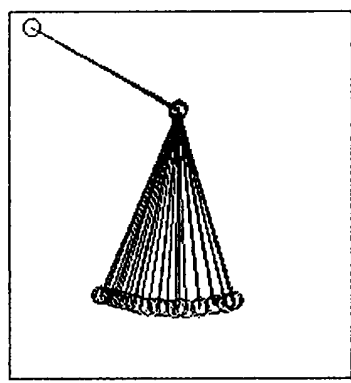

(a) Reference leg motion

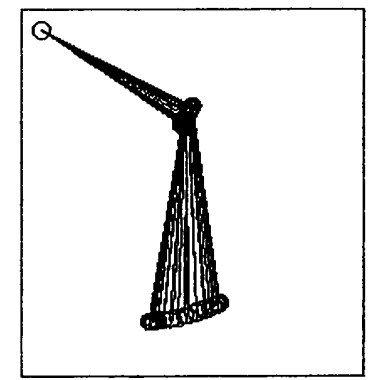

(b) Leg motion using linkage Fig. 8 Motion of leg with device

\section{3-2 踏力の測定}

ひずみゲージを用いて本研究室で製作した踏力測定装置 を片麻福者用車いすに取り付け,片麻㾝者用車いす使用時の 踏力の測定実験を行った.Fig.9(a)に健常者通常歩行時の踏力 測定結果を, Fig.9(b)に片麻痷者用車いす使用時の踏力測定結 果を示す.これらのグラフにおいて, 横軸は一周期分の歩行動 作の時間を,縦軸は床反力の大きさを示している.なお,図中の $\mathrm{x}$ force, $\mathrm{y}$ force は床から水平方向・垂直方向に受ける力であ り,Fig.9(b)においては装置のペダルを基準とし,水平方向・垂 直方向に受ける力である.

\section{4.まとめ}

本研究では,股関節の可動域を制限し,かつ座面と床の間の 空間に機構を収めるために,スライダを使用した 6 節リンク 機構を考案し,空間に制約をかけ機構定数を決定し,成人男性 の装置の駆動から各関節の動作とそのときの踏力を検証し た.

3 章で参照した各関節の動きと,装置を使用した際の各関 節の動きを比較すると,膝関節は参照值に対して変位は小さ いものの動作が確認できたが,股関節は参照值では動作が見 られないのに対して動作していることがわかるこれは、機構 定数を決定する際,座面と床の間の空間にリンク機構を収め ることを優先したために,リンク長に制約が生じてしまい,参 照值に対応できる十分な長さを確保できなかったためと考 えられる.しかし,角変位の测定の結果より,装置を使用するこ とにより健側に追従して動くこととなる患側脚部に反復運 動を実現し,脚部にある程度の可動域を確認することができ る.

また,踏力の測定結果から,健常者の歩行時と比べると,片麻 㿎者用車いす使用時のほうが小さい力での駆動が可能とい うことがわかる.これは,装置使用時の慣性による力の影響も 考えられるが,使用可能な健側の腕力も手伝い,方麻瘏者の脚 部に無理な負担をかけることなく装置の駆動が可能である と言える.しかし,健常者の通常歩行時の踏力と比較している ため,装置使用時の踏力の波形を検証するには至っておらず, 今後は,通常車いす使用時の踏力も測定し,装置使用時との比 較を行う予定である.また,より安全でかつ有効な可動域が得 られるように機構や構造を見直し,装置を使用した際のリ八 ビリテーション効果についても検証する.

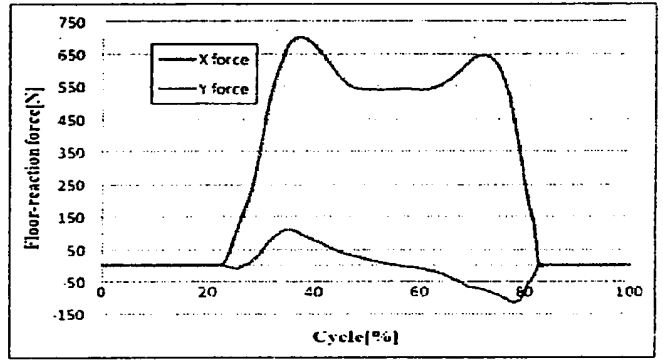

(a) Floor reaction force

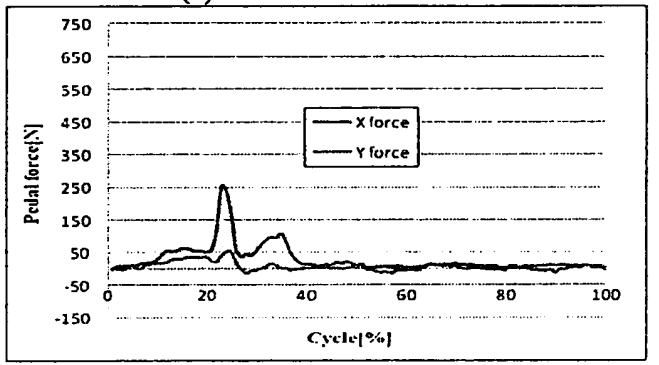

(b) Pedal force

Fig.9 Force acting on foot 